Ann. Biol. anim. Bioch. Biophys., 1977, 17 (3 B), 425-439.

\title{
Central neurotransmitters and control of prolactin secretion
}

\author{
par C. KORDON, A. ENJALBERT, L. CARBONELL
}

Laboratoire de Neuroendocrinologie (U.159), Centre Paul Broca de I'I.N.S.E.R.M.

2 ter rue d'Alésia 75014 Paris, France

\section{Introduction.}

Despite extensive study during the last 10 years, several aspects of the neural control of prolactin secretion are still unelucidated. In mammals, the most important feature of this control is the existence of a predominant inhibitory regulation, as demonstrated by a number of older experiments involving hypothalamo-hypophyseal deconnexion, interruption of the portal circulation, ectopic grafts of the pituitary, as well as in vitro incubations of adenohypophyseal tissue (see review in Meites and Nicoll, 1966 and Pasteels, 1967). Under all these conditions, elimination of hypothalamic influences induces a remarkable stimulation of prolactin secretion. This powerful repressor effect of the hypothalamus often masked more limited stimulatory effects, which, nevertheless, can be expressed under certain physiological or experimental conditions. In other species like birds (Kragt and Meites, 1965 ; Gourdji and TixierVidal, 1966), such stimulatory effects even appear more important than the inhibitory component of the regulation.

The complexity of mechanisms regulating prolactin release reflects the large variety of physiological situations in which changes in prolactin levels can be observed (stages of the estrous cycle, pregnancy, lactation, stress etc.). A variety of inputs may thus result in elevated prolactin production. In the present paper, we will attempt to describe some of the neural factors which modulate the release of prolactin, focussing our attention particularly on the role of neurotransmitters and neurohormones.

\section{General aspects of neurotransmitter-neurohormone interactions.}

Detection of neurotransmitter-neurohormone interactions is not easy, because each transmitter system involves a great number of neural projections which are distributed throughout the Central Nervous System (CNS) (Anden ef al., 1966) ; each one of these tracts can theoretically affect endocrine regulation. Neurotransmitters have been shown to intervene at each of the hierarchised hypothalamic or extrahypothalamic levels which are responsible for hormonal control (see review in Kordon 
and Glowinski, 1972). The data are still contradictory, perhaps because of limitations inherent in the pharmacological methodology used in most experiments. It must be stressed that drugs given systemically to affect the metabolism or the release of a given transmitter will interfere simultaneously with all structures concerned with neuroendocrine control. Under these conditions, the overall resulting response which is observed can hardly be ascribed to direct, rather than to secondary effects, of the drug. Only structure by structure analyses of neurotransmitter turnover in different endocrine states or micropharmacological studies will, in the long run, result in a better understanding of the aminergic mechanisms underlying neural control of endocrine functions.

The multiplicity of aminergic synapses also provides an explanation for the fact that a transmitter may have different effects on the secretion of a hormone under basal conditions, or when secretion is induced by a neural stimulus (Kordon, 1973). The neuronal circuitry involved in «hormonostatic » regulation or in adapting endocrine responses to external stimuli (《 neuroendocrine reflexes») are not the same. Synaptic facilitation by a given transmitter does not necessarily have the same effect in both cases.

For these reasons, the most clearcut data on neurotransmitter neurohormone interactions are derived from in vitro experiments. In vitro techniques can be applied to the pituitary, but also to the median eminence ; for the latter, neurohormone release is measured after incubation of tissue slices or of subcellular fractions containing neurosecretory endings (synaptosomes or neuro-secretosomes). Such preparations have been used so far mainly for studying LHRH, TRH or CRF regulation (Bennett ef al., 1975 ; Rotsztejn ef al., 1976). However, incubation of the pituitary itself in the presence of neurotransmitters has proven a valuable tool to elucidate the mechanisms of prolactin control, as will be seen in the next section.

We will review separately the effects of aminergic transmitters on prolactin control, first at the hypothalamic level and, then, at the level of the pituitary.

\section{Involvement of monoamines in the hypothalamic regulation of prolactin secretion.}

As suggested by pharmacological experiments or by infusion of neurotransmitters into the third ventricle, at least two amines are likely to interfere at the hypothalamic level with prolactin regulation mechanisms : noradrenaline (NA) and serotonin (5-HT) (MacCann et al., 1972 ; Kamberi et al., 1971). The case of a third amine, dopamine (DA), will be reviewed in the next section, since its main impact lies at the hypophyseal level.

Both NA and 5-HT seem to stimulate the release of prolactin. It is, however, extremely difficult to ascribe a precise physiological role to this stimulation because it is based mainly on experiments involving intraventricular administration of large amounts of transmitters, diffusion of which to periventricular structures might cause artefactual responses.

In contrast, studies on the suckling-induced prolactin release in lactating animals yield more clearcut conclusions on the physiological involvement of 5-HT. This response is one of the best known neuroendocrine reflexes. In the rat, after pups have been 
removed from their mother for an adequate period of time, the suckling stimulus results in a very marked elevation (about 10-fold) of plasma prolactin concentrations within 5 to $10 \mathrm{~min}$ (Grosvenor and Mena, 1972 ; Terkel et al., 1972 ; Kordon et al., 1973). Under these conditions the amount of hormone very rapidly released by the pituitary corresponds to 20 p. 100 of the total content of the gland ; similar values were also calculated independently by Grosvenor and Mena, who measured pituitary content depletion by bioassay. In contrast to the oxytocic response to the suckling reflex, which lasts no more than a few seconds but recurs at regular intervals, prolactin secretion and high plasma levels of the hormone can be maintained in lactating rats as long as the suckling stimulus remains applied (Grosvenor and Mena, 1972).

The neural pathway involved in the suckling reflex has mainly been studied on the basis of oxylocic responses (Yokohama el al., 1967 ; Richard, 1970 ; Richard ef al., 1970). One may infer that the same pathway is involved in the prolactin response. It can be concluded from lesion and deafferentation experiments that influxes generated by suckling first follow fibers from the posterior medullary roots (Richard, 1970) up to the mesencephalon. From there, two ascending projection systems convey the suckling information to the hypothalamus : the bundle of Schütz and the Medial Forebrain Bundle (MFB) (Averill and Purves, 1966). The kinetics and the intensity of the hormonal response to suckling make the lactating animals a good preparation for shortterm pharmacological experiments, because side-effects or non-specific responses can be kept to a minimum.

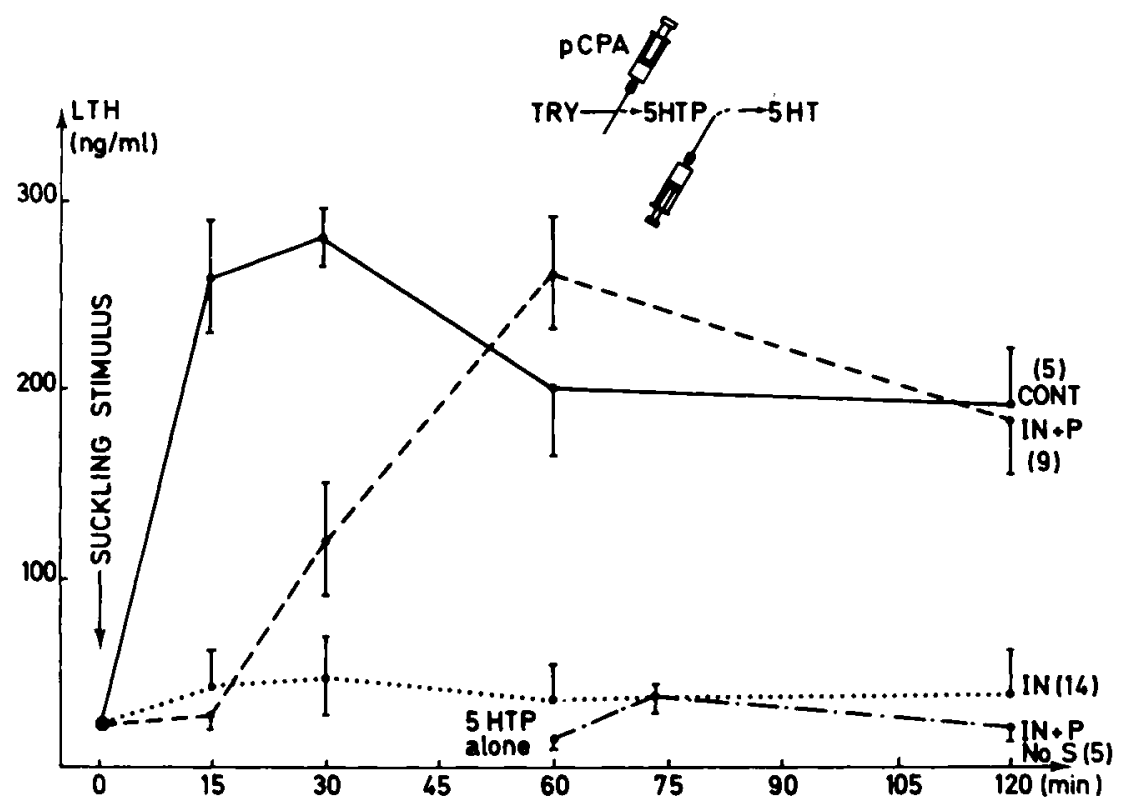

FIG. 1. - Plasma prolactin response to suckling in untreafed lactating rats (— biosynthesis inhibition by PCPA $(\ldots \ldots)$ or after subsequent restoration of $5 H T$ levels (PCPA + 5HPT) (-- -). 5HTP without suckling (---) is ineffective by itself. CONT = Controls ; IN : 5HT inhibitor ; $P$ : precursor ; No $S=$ no suckling (from Kordon ef al., 1973). 
Inhibition of 5-HT biosynthesis blocks the suckling-induced prolactin response (Kordon et al., 1973) (fig. 1). The response remains inhibited as long as endogenous serotonin stores remain depleted. Administration of the immediate precursor of the amine, 5-hydroxytryptophan (5-HTP), induces a parallel restauration of the prolactin (Kordon ef al., 1973) and of normal endogenous 5-HT levels in the CNS (Héry et al., 1976) (fig. 1).

Serotonin can thus be assumed to have a positive effect on the suckling-induced prolactin release, since suppression of the amine eliminates the prolactin response. However, the concept of a facilitatory effects is more appropriate, for, as seen on figure 1, restauration of normal or above normal levels of 5-HT by administration of the precursor does not by itself affect prolactin release in the absence of the suckling stimulus (Kordon et al., 1973).

What does this facilitatory effect mean, and to what extent can one localize its impact? Recent data provide a partial answer to this question. Under adequate conditions of separation of the pups (approximately $8 \mathrm{hrs}$, an interval shown to permit optimal reflex prolactin secretion in the rat), the suckling stimulus induces a significant decrease in hypothalamic 5-HT concentrations within $5 \mathrm{~min}$ (fig. 2). This depletion is not observed in other CNS structures (Mena et al., 1976) and is maintained for at least $60 \mathrm{~min}$, if the stimulation is continued. In parallel, levels of a 5-HT metabolite, 5-hydroxyindolacetic acid (5-HIAA), increases in the hypothalamus, but not elsewhere in the CNS (Mena ef al., 1976) (fig. 2). When considered together these two observations strongly suggest that suckling induces an activation of 5-HT-containing neurons ; only those neurons projecting to the hypothalamus seem to be involved. This result in an increase of the terminal release of the amine under time conditions which appear strictly correlated with those of hormone release.

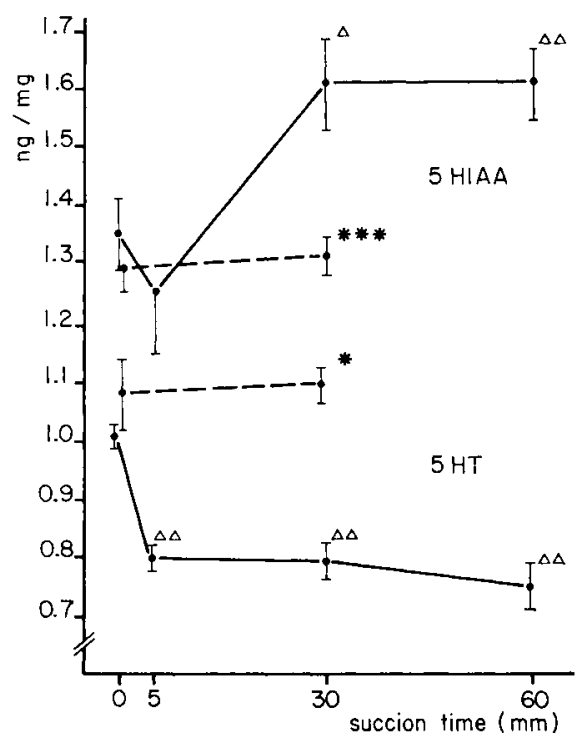

FIG. 2. - Hypothalamic 5HT and 5HIA concentrations at various intervals of suckling in lactating mothers separated from their pups for 8 (solid line) or 24 hours (broken line) (from Mena et al., 1976). 
This correlation between an activation of 5-HT release and pituitary prolactin secretion is even more striking if one considers that, when the experiment is performed after a longer period ( $\geqslant 24$ hrs of separation of the pups, that is, under « preweaning 》 conditions), neither a normal prolactin release (Grosvenor and Mena, 1972) nor a decrease in hypothalamic 5-HT (Mena ef al., 1976) any longer occur. Thus, suckling-induced prolactin secretion seems to depend upon the capacity of the suckling stimulus to stimulate serotoninergic pathways terminating in the hypothalamus.

These data provide an explanation of the finding that two distinct ascending pathways are involved in the hormonal response associated with suckling. On the one hand, the bundle of Schütz seems mainly important for transmission of the specific suckling reflex to the $\mathrm{MBH}$. On the other hand, the MFB, which contains most of the aminergic ascending projections (Anden et al., 1966), would convey 5-HT mediated facilitatory information to the hypothalamic effector neurons which regulate prolactin secretion.

Under strictly similar experimental conditions, noradrenalin concentrations are not modified by suckling in any CNS structures. In contrast, hypothalamic dopamine is affected by suckling ; this results either in an increase of the turnover of the amine (Voogt and Carr, 1974), or in a decrease of its hypothalamic levels (Mena et al., 1976), or of its specific fluorescence (Leonardelli, unpublished results). All these observations suggest that the terminal release of dopamine is increased under these condifions, but the meaning of this change is not yet well understood.

At this stage, the available data on transmitter involvement in prolactin regulation at the level of the hypothalamus can be summarized as follows :

1) The existence of a stimulatory effect of both NA and 5-HT on base-line secretion levels of the hormone is likely.

2) The involvement of 5-HT appears better established in the suckling-induced prolactin secretion. Under these conditions, it has a facilitatory effect (positive modulation) on the hormonal response. It is as if an increase in hypothalamic 5-HT transmitted through the MFB sensitizes neurosecretory neurons towards the specific information transmitted by the bundle of Schütz.

3) Under weaning conditions, an identical mammary stimulus is no longer able to affect hypothalamic 5-HT, or, parallely, to induce a massive release of prolactin.

4) Hypothalamic dopamine is also affected by the suckling reflex.

\section{Factors affecting the pituitary}

\section{A. The problem of dopamine.}

It has been known for a long time that any drug interfering with the metabolism of DA or with the receptors of the amine has a spectacular effect on prolactin secretion (Meites, 1970 ; Lu et al., 1970). In fact, dopamine and its agonists are very powerful inhibitors of prolactin release, under all experimental conditions tested so far.

This effect has its impact directly on pituitary prolactin cells themselves. Addition of increasing doses of DA to an incubation medium containing pituitaries results in a proportional inhibition of in vitro prolactin release (Shaar and Clemens, 1974 ; McLeod 
and Lehmeyer, 1974). This effect can already be seen with very low concentrations of DA (less than $10^{-8} \mathrm{M}$ ). DA agonists like apomorphine or bromoergocryptine have a parallel effect (Smalstig ef al., 1974), whereas specific or partial antagonists of the amine on its receptor sites, like haloperidol, inhibit the action of DA (Smalstig ef al., 1974 ; Enjalbert et al., 1977) (fig. 3). These interactions account for most drug-induced modifications of prolactin secretion described so far.

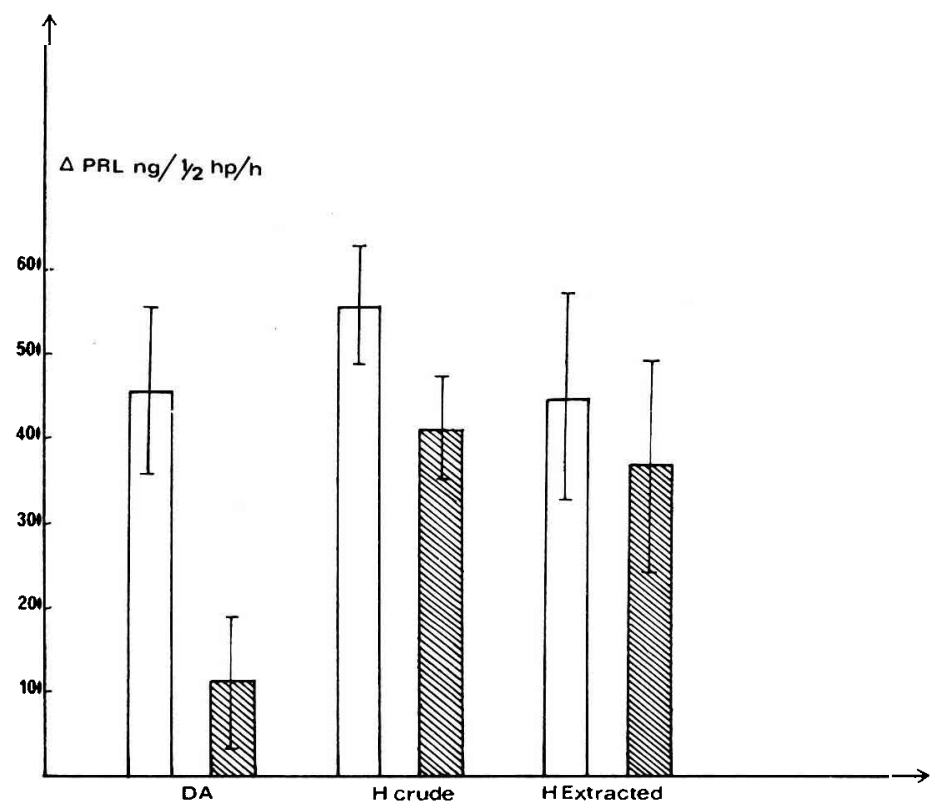

FIG. 3. - Effect of haloperidol $\left(10^{-5} \mathrm{M}\right)$ on the prolactin inhibiting activity of $D A$ and of crude or DA-free hypothalamic extracts. Incubations without (open bars) or with (striped bars) the DA receptor inhibitor ; results are expressed as difference in prolactin concentration ( $\triangle \mathrm{PRL})$ between one half pituitary incubated with DA or extract and the other half incubated alone.

Characterization of DA receptors in the pituitary, which are likely to be located on the membrane of prolactin cells, is far from completed. They may be similar to central DA receptors, as recently suggested on the basis of binding experiments on membranerich subcellular fractions (Brown ef al., 1976) or of hypersensitization after destruction of the DA innervation of the median eminence (Cheung and Weiner, 1976). However, this does not meet complete agreement (Kordon and Rotsztejn, 1976) and must still be confirmed.

$D A$ reaching the pituitary originates in the tuberoinfundibular neuron system. Evidence that DA involved in pituitary control comes from that fiber tract can be very clearly inferred from experiments with hypothalamic deafferented animals. Under these conditions, DA is the only known neurotransmitter in the deafferented fragment not to be affected by the surgery (Weiner, 1975), since the tuberoinfundibular DA system lies entirely within the limits of the mediobasal hypothalamus. The levels of NA or 5-HT are, in contrast, markedly depleted. Similarly basal prolactin secretion 
is totally unaffected by the surgery (Weiner, 1975) but subsequent administration of antagonists or biosynthesis inhibitors of DA is followed by an increase of prolactin release, exactly as in normal animals (fig. 4).

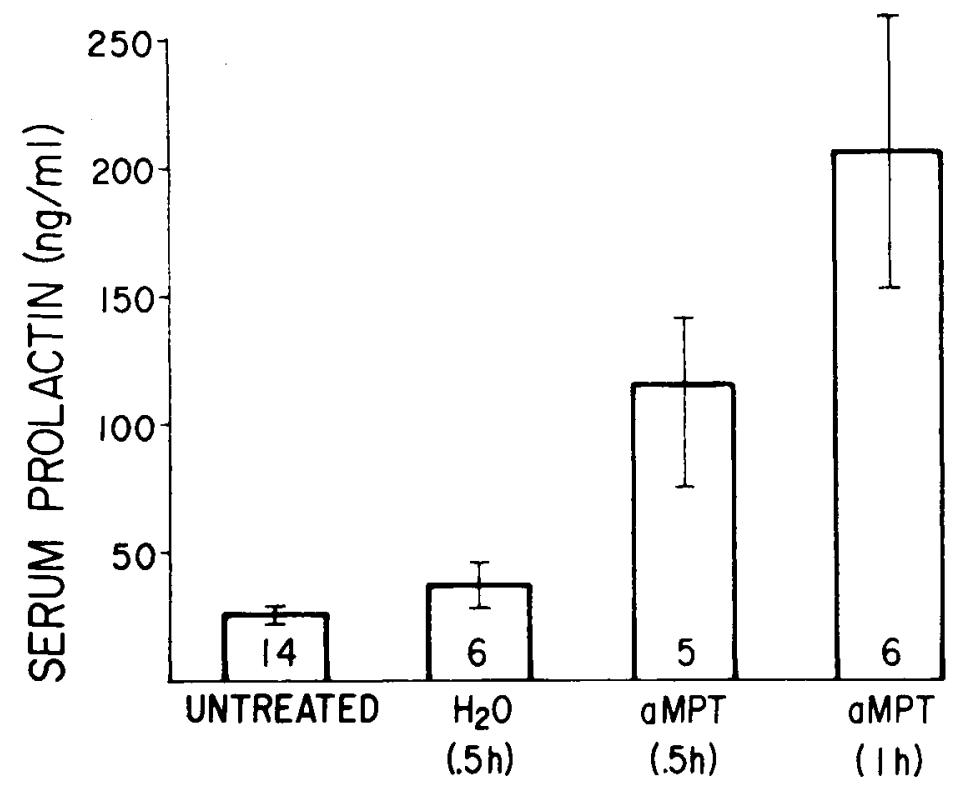

FIG. 4. - Effect of drugs affecting dopamine receptors on proloctin release from animals with complete hypothalamic deafferentation (from Weiner, 1975).

Data on prolactin regulation in birds provide us with additional evidence of the importance of the tuberoinfundibular system. As mentioned above, in this species unlike in mammals, there is no inhibitory hypothalamic regulation of prolactin release; neither are there dopaminergic tuberoinfundibular neurons (Calas, 1976).

Tuberoinfundibular DA neurons exhibit properties which are not strictly comparable to those of other central dopaminergic neurons. Prolactin and estradiol (Hökfelt and Fuxe, 1972) for instance affect the metabolism of tuberoinfundibular DA, but are ineffective on other DA containing tracts, like the nigrostriatal system for instance (Lichtensteiger, 1969, Gudleksy ef al., 1976). Conversely, some fundamental properties of central dopaminergic systems are not present in the tuberoinfundibular tract. For example, 6-OH-DA, an analog of dopamine which induces complete and irreversible degeneration of central catecholaminergic neurons (Ungerstedf, 1968) has only partial and transient effects on the DA neurons ending in the median eminence (Kizer et al., 1975). The administration of agonists or antagonists of the neurotransmitter which, respectively, inhibit or stimulate DA biosynthesis in the striatum, does not seem to affect the tuberoinfundibular system (Gudleksy ef al., 1976).

Finally, it is possible that periventricular DA neurons (Bjorklund ef al., 1975) play a role in the control of prolactin secretion. The sites to which these neurons project 
have not yet been clearly identified. Observations by Shoemaker (1976) that the specific fluorescence of the cell-bodies of these neurons undergoes changes during lactation could suggest that they are involved in prolactin control; this hypothesis is all the more tempting in that the distribution of these cell-bodies closely corresponds to that of projections from the bundle of Schütz, the importance of which in lactation has been stressed.

\section{B. Other hypothalamic factors which inhibit prolactin secretion.}

Since the initial demonstration of hypothalamic inhibition of prolactin secretion, many attempts have been made to characterize the factor responsible for this inhibition (PIF). It seems clear today that in most of these experiments, DA accounted for the PIF activity seen in median eminence. As an indication, one median eminence contains 3 to $5 \mathrm{ng}$ of DA; in an incubation volume of $1 \mathrm{ml}$ this represents a concentration of about $2 \cdot 10^{-8} \mathrm{M}$. But in addition to DA, the existence of PIF in proteic fractions after chromatographic separation has been claimed (Schally ef al., 1976 ; Greibrokk ef al., 1975), though other authors still consider it controversial (Shaar and Clemens, 1974).

It seems, however, that DA can not account for all inhibitory effects of hypothalamic extracts. After subcellular fractionation of the mediobasal hypothalamus, the two main fractions (a high speed supernatant $S_{2}$ and a mitochondrial fraction $P_{2}$ containing synaptosomes and mitochondria) contain large amounts of PIF. After elimination of DA from these fractions by adsorption on alumina oxide, PIF activity disappears completely from the supernatant $S_{2}$ indicating that, in this fraction, PIF activity is

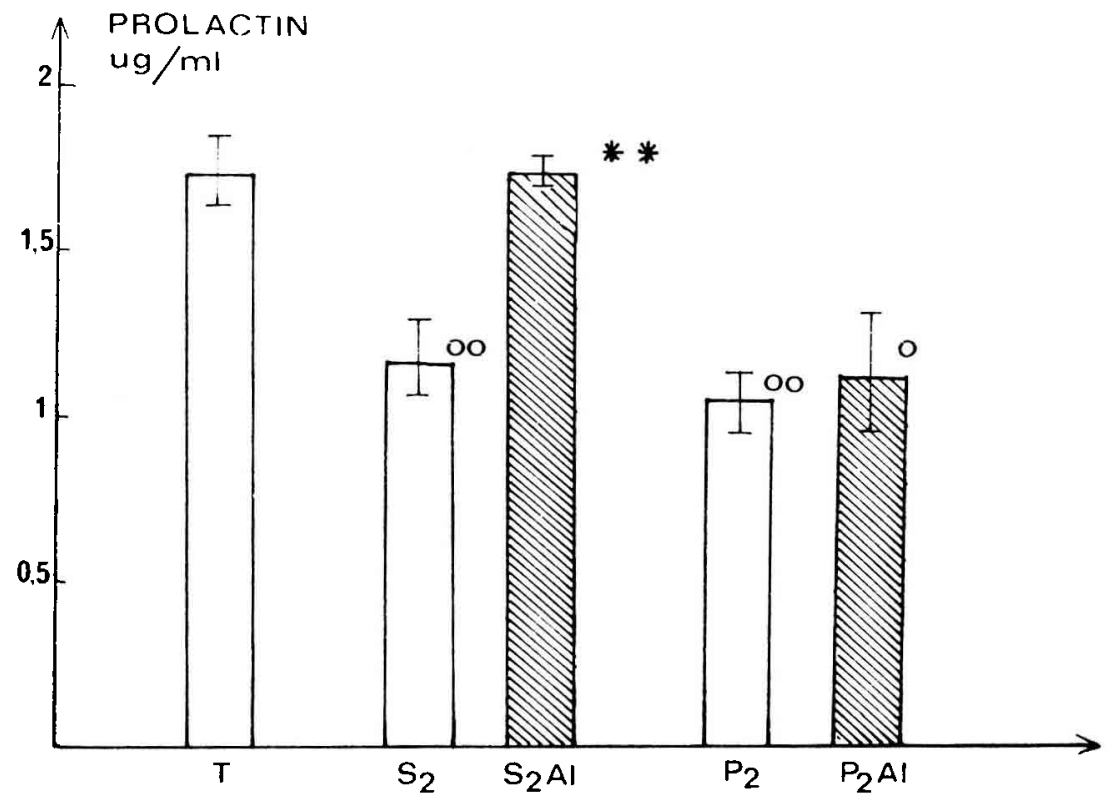

FIG. 5. - In vitro prolactin release of control pituitaries (T), or of pituitaries incubafed with the high speed supernatant $\left(\mathrm{S}_{2}\right)$ or the crude mitochondrial fraction $\left(\mathrm{P}_{2}\right)$ derived from hypothalamic fragments. $\mathrm{AlO}_{3}$ extraction removes prolactin inhibiting activity from $\mathrm{S}_{2}$, but not from $P_{2}$. 
entirely due to DA. In contrast, elimination of over 99.9 p. 100 of DA content from the synaptosomal fraction $P_{2}$ decreases PIF activity of this fraction (fig. 5 ) by only one third (Enjalbert ef al., 1976). In addition, PIF activity from the synaptosomal fraction is not inhibited by DA antagonists, which block the effect of $S_{2}$ and, of course, of DA itself (fig. 3).

It seems, then, that a PIF other than DA is contained in nerve terminals of the hypothalamus, probably in neurosecretory endings. Such an exclusively synaptosomal distribution is identical to that described for all other neurohormones tested so far (LHRH, Ramirez ef al., 1975 ; Shin ef al., 1974 ; Taber and Karavolas, 1975 ; TRH, Barnea ef al., 1975 ; SRIF, Epelbaum ef al., 1976). This similarity suggests that nondopaminergic PIF could be a peptide related to the other neurohormones.

Recent observations that the non-dopaminergic PIF content and the endogenous DA concentration in the mediobasal hypothalamus are not affected parallely by suckling can also be taken as an argument in favouring the existence of two separate PIF factors (Carbonell et al., 1976).

The negative results obtained by Shaar and Clemens (1974) after elimination of DA from their extracts are probably due to excessively long incubations. Under these conditions, in vitro PIF assays are less sensitive than after shorter incubations, and nondopaminergic PIF is likely to be degraded by peptidasic enzymes, as are most neurohormones.

\section{Factors stimulating pituitary prolactin secretion.}

The existence of a prolactin-releasing factor was first postulated to account for the predominance of a positive hypothalamic regulation of prolactin secretion observed in birds (Kragt and Meites, 1965 ; Gourdji and Tixier-Vidal, 1966). In order to

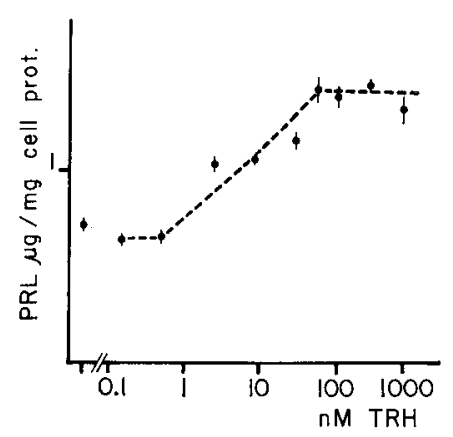

FIG. 6. - Effect of increasing doses of $\mathrm{TRH}$ on prolactin release from cultivated $\mathrm{GH}_{3}$ cells (B6 subclone). Cells were incubated for $30 \mathrm{~min}$. at $37^{\circ} \mathrm{C}$ after 5 days of preincubation in Ham F10 enriched by heat-inactivated serum (Gourdji, unpublished observation).

account for the rapid and massive prolactin secretion observed during lactation, the hypothesis of a PRF was extended to mammals. The discovery that TRH itself is capable of releasing prolactin in vivo and in vitro further complicates the problem (fig. 6). 
Without reviewing here all arguments suggesting that TRH is a prolactin-secreting substance (Tashjian ef al., 1971 ; Gourdji ef al., 1972), let us recall that it acts on membrane receptors; the kinetics of an association of the hormone to membrane fractions has been demonstrated (Tixier-Vidal ef al., 1975 ; Labrie et al., 1976). An uptake of TRH into pituitary cells seems also to occur with a possible association of the hormone to a nuclear component (Tixier-Vidal ef al., 1975). Such heferogeneity of sites of action - involving membrane as well as intracellular receptors - could be related to a differential effect of the hormone on the release of presynthetized prolactin, on one side, and on neosynthesis, on the other hand, but this is still a matter of speculation.

In addition, somatostatin is able to inhibit the effects of TRH on prolactin secretion and on concomitant cyclic AMP production (Labrie et al., 1976).

Neurotransmitters are also involved in the control of TRH and somatostatin release, and could, thus, affect prolactin by an indirect action on these neurohormones.

Despite several attempts to demonstrate its existence, there is no convincing evidence as yet in favour of a PRF distinct from TRH. Research on this line is fairly difficult, because PIF activity predominates in hypothalamic extracts. Besides the several negative experimental results obtained, data by Boyd ef al. (1976) and Terkell (personal communication) suggest that a PRF-like factor could be present in hypothalamic or plasma extracts under certain conditions.

\section{Summary and conclusion}

\section{A. DA and the fuberoinfundibular system.}

The most clearcut data concerning the regulatory role of neurotransmitters in prolactin secretion concern DA. This regulation is probably one of the main functions of the tuberoinfundibular system (Weiner, 1975). What is known on the physiological significance of this action?

Dopamine could well play an important role in the regulation by prolactin on its own secretion (shorf feedback) as well as in mediating the effect of steroids on the control of the pituitary hormone. We have seen that prolactin and estradiol (Hökfelt and Fuxe, 1972) increase the turnover rate of tuberoinfundibular DA. Their action on pituitary secretion could be, at least in part, accounted for by this mechanism shown on figure 7 together with a schematic diagram of the neuronal and hormonal inputs participating in prolactin regulation.

The physiological role of tuberoinfundibular DA in lactation is not well understood. The parallelism between suckling-induced DA release and prolactin secretion appears paradoxical. How can a powerful inhibitory factor reach the pituitary at increased concentrations while the gland is massively releasing prolactin ? It has been suggested that this increase of the furnover of the amine could be related to the abrupt interruption of prolactin secretion which occurs at the end of suckling (Mena ef al., 1976) ; it could also explain the onset of a refractory period after a phase of suckling which has been reported to occur in the rat (Grosvenor and Mena, 1973). However, the existence of such a refractory period is still denied by other authors (Terkel ef al., 1972). 


\section{B. Serotonin.}

As we have seen, serotonin seems primarily to regulate induced prolactin secretion. The exact mechanisms of this interaction have not been investigated as yet. Hypothetically, the transmitter could modulate the synthesis or release of PIF, or PRF, or event TRH, as represented on figure 7 , by directly affecting the neurosecretory neurons elaborating these neurohormones, or by indirectly sensitizing the neuronal circuitry which, secondarily, affects hypothalamic neurosecretory processes. The changes in DA turnover observed during lactation could themselves be monitored by changes in serotonin activity in the mediobasal hypothalamus.

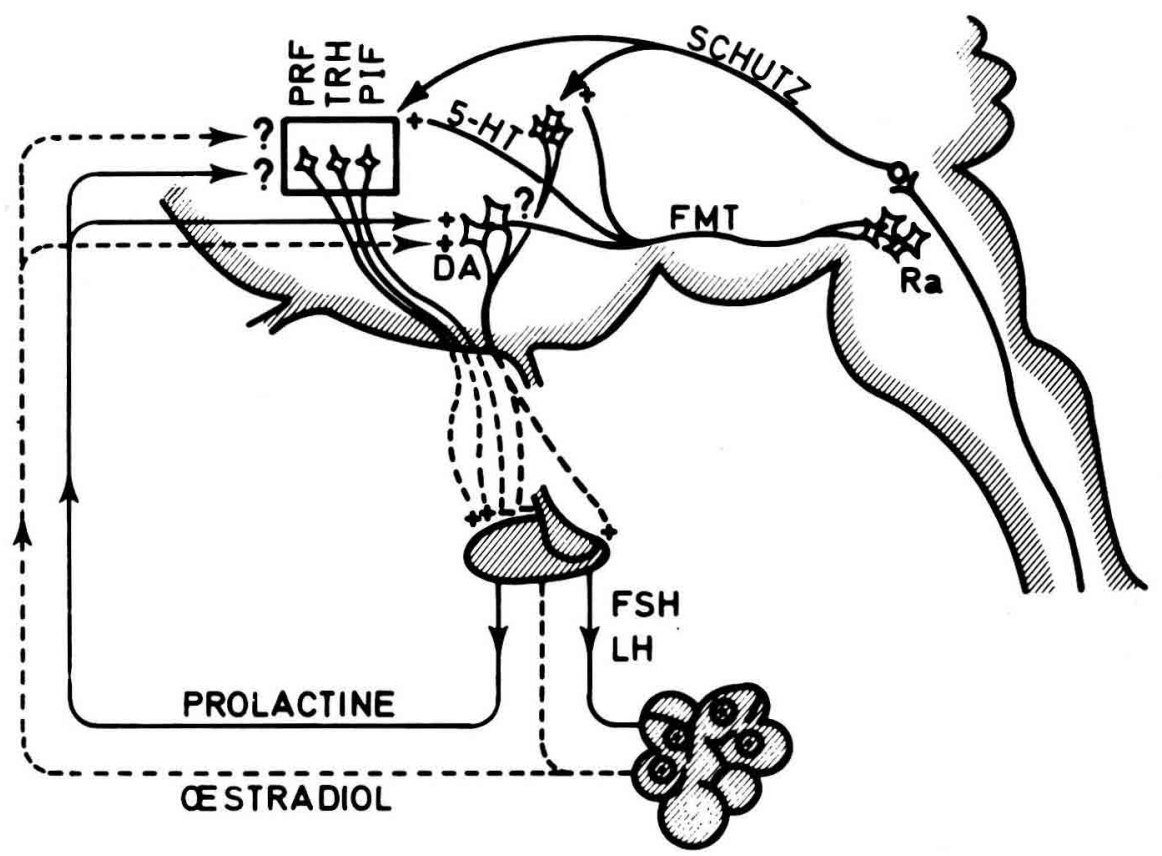

FIG. 7. - Schematic representation of the neural and hormonal inputs participating in prolactin regulation. FMT = median forebrain bundle; Ra, Raphé nuclei.

At any rate, the role of $5-\mathrm{HT}$ in the suckling reflex is of a permissive nature only. Thus, the amine can be considered to have a modulatory function on the sensitivity of neurosecretory cells involved in prolactin control. It is not stricto sensu a transmitter conveying a specific somesthetic information. Modulation is likely to be a general characteristic of aminergic transmission, and the word « neuromodulator» may be more appropriate to define it than the classical term of «neurotransmitter ». In addition, recent morphological observations by Descarries ef al. (1975) provide an anatomical basis for this concept. These authors have demonstrated that, in the cerebral cortex, most 5-HT containing nerve endings do not form conventional synapses, with a synaptic cleft and a postsynaptic thickening; they are distributed instead as a diffuse 
projection system, from which the amine may be able to reach most, if not all, cellbodies located in the vicinity and thus modulate their overall sensitivity.

What can be said about the physiological relevance of this serotoninergic mechanism ? In the first place, the facilitatory effect of 5-HT seems to play a role in the onset of weaning. 5-HT neurons involved in this control may act as « memorizers » of « lactation programs »: when the circuitry of the suckling reflex has not been in use for a certain period, 5-HT neurons seem to be desensitized, which no longer permits neurosecretory elements to become activated.

It is also tempting to speculate that serotonin may be involved in the inhibition of ovulation, which occurs during lactation. 5-HT can be inhibitory to gonadotropic secretion (O'Steen, 1965 ; Kordon ef al., 1968 ; Kamberi ef al., 1971). An elevation of serotoninergic « tuning» could thus simulataneously facilitate prolactin response to suckling and antagonize LH secretion ; conversely, a decreased tuning would desensitize prolactin triggering neurons and restore a normal phasic pattern of $\mathrm{FSH}$ and $\mathrm{LH}$ secretion. Dopaminergic mechanisms responsive to suckling could also intervene in the antagonistic equilibrium of prolactin and gonadotropic secretion seen under most physiological conditions.

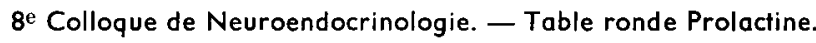

Tours, 7 septembre 1976.

Acknowledgments. - The authors are indebted to Miss Evelyne Smith for her very skilled secretarial assistance.

Résumé. La sécrétion de la prolactine hypophysaire est contrôlée par des circuits neuronaux complexes, qui impliquent l'intervention de plusieurs médiateurs du Système Nerveux Central. L'interaction la mieux établie entre un médiateur et la régulation de l'hormone est assurée par la dopamine. Il s'agit, dans ce cas, d'une action directe au niveau hypophysaire, et l'existence de récepteurs spécifiques de l'amine au niveau de la cellule à prolactine de mammifères a été démontrée. La mise en jeu de ces récepteurs par de très faibles quantités de dopamine ou d'agonistes du neurotransmetteur induit une inhibition marquée de la libération de prolactine ; inversement les antagonistes de la dopamine ou les inhibiteurs de sa biosynthèse ou de sa libération entraînent une hyperprolactinémie rapide dans toutes les situations physiologiques ou expérimentales étudiées. Cette régulation de la prolactine est assurée par le système dopaminergique fubéro-infundibulaire. Des modifications de la vitesse de renouvellement de l'amine dans ce système de neurones peuvent être induites par la prolactine elle-même, et permettent ainsi d'expliquer, au moins en partie, l'existence d'une rétroaction courte de l'hormone sur sa propre sécrétion. Il est en outre intéressant de constater que les oiseaux, qui ne présentent pas de régulation hypothalamique inhibitrice de la sécrétion de prolactine, sont parallèlement dépourvus de neurones tubéro-infundibulaires dopaminergiques.

D'autres médiateurs concourent également au contrôle de la sécrétion de prolactine, mais leurs effets s'exercent principalement au niveau hypothalamique. Le mieux connu de ces effets concerne la facilitation par la sérotonine de la sécrétion de prolactine induite par la succion chez la femelle lactante. Dans ce cas, l'amine n'affecte pas le taux de sécrétion basal de l'hormone; l'importance physiologique de cette interaction est attestée par le fait que la succion accélère électivement la libération de la sérotonine hypothalamique. En outre, le sevrage semble s'accompagner d'une baisse de la réactivité de neurones à sérotonine aboutissant à l'hypothalamus.

Mis à part l'effet de la dopamine sur l'hypophyse, l'intervention de neurotransmetteurs dans la sécrétion de prolactine s'exerce par l'intermédiaire de neurohormones. L'action 
directe de médiateurs sur la sécrétion de ces neurohormones est encore mal connue ; elle implique sans doułe des modulations de la libération du TRH, dont l'effet stimulant de la sécrétion ce prolactine est bien établi, ainsi que de la libération d'un PIF distinct de la dopamine dont l'existence est suggérée par plusieurs expériences récentes.

\section{References}

ANDEN N. E., DAHLSTROM A., FUXE K., LARSSON K., ORSON L., UNGERSTEDT W., 1966. Ascending monoamine neurons to the telencephalon and diencephalon. Acta physiol. scand., 67, 313-326.

AVERILL R. L. W., PURVES M. D., 1966. Differential effects of permanent hypothalamic lesions on reproduction and lactation in rats. J. Endocrin., 26, 463.

BARNEA A., BEN-JONATHAN N., COLSTON C., JOHNSTON J. M., PORTER J. C., 1975. Differential subcellular compartimentalization of thyrotropin-releasing hormone (TRH) and gonadotrophin-releasing hormone $(\mathrm{LRH})$ in hypothalamic tissue. Proc. nat. Acad. Sci., Wash., 72, 3163.

BENNETT G. W., EDWARDSON J. A., HOLLAND D., JEFFCOATE S. L., WHITE N., 1975. Release of immunoreactive luteinizing hormone releasing hormone and thyrotrophin releasing hormone from hypothalamic synaptosomes. Nature, 257, 323.

BJORKLUND A., LINDVAL O., NOBIN A., 1975. Evidence of an incertohypothalamic dopamine neurone system in the rat. Brain Res., 89, 29-42.

BOYD III A. E., SPENCER E., JACKSON I. M. D., REICHLIN S., 1976. Prolactin releasing factor (PRF) in porcine hypothalamic extract distinct from TRH. Endocrinology, 99, 861.

BROWN G. M., SEEMAN P., LEE T., 1976. Dopamine, neuroleptic receptors in basal hypothalamus in pituitary. Endocrinology, 99, 1407.

CALAS A., 1976. Radioautographic studies of aminergic neurons terminating in the median eminence. In E. COSTA, Non-striatal dopaminergic neurons. Raven Press, New York (in press).

CARBONELL L., ENJALBERT A., MOOS F., 1976. Effet de la succion sur les facteurs hypothalamiques contrôlant la sécrétion de prolactine chez la ratte. J. Physiol., Paris, 72, 13.

CHEUNG C. Y., WEINER R. I., 1976. Supersensitive dopamine receptors and prolactin secretion. V. Int. Congr. Endocrin., Abstr. no 195.

DESCARRIES L., BEAUDET A., WATKINS K. C., 1975. Serotonin nerve terminals in adult rat neocortex. Brain Res., 100, 563.

ENJALBERT A., CARBONELL L., PRIAM M., KORDON C., 1976. Further evidence in favour of the existence of dopamine (DA) free prolactin inhibiting factor (PIF) in rat hypothalamic extracts (HE). V. Inter. Congr. Endocrin., Abstract no 25.

ENJALBERT A., PRIAM M., KORDON C., 1977. Evidence in favour of the existence of a dopaminefree prolactin inhibiting factor (PIF) in rat hypothalamic extracts. Eur. J. Pharmacol., 41, 243.

EPELBAUM J., BRAZEAU P., TSANG D., BRAWER J., MARTIN J. B., 1976. Subcellular distribution of somatostatin in the rat brain. Brain Res., 102, (in press).

GOURDII D., KERKELHUÉ B., TIXIER-VIDAL A., 1972. Ulirastructure d'un clone de cellules hypophysaires sécrétant de la prolactine (clone GH3). Modification induite par l'hormone de libération de I'hormone thyréotrope (TRF). C. R. Acad. Sci., Poris, Série D, 274, 437.

GOURDJI D., TIXIER-VIDAL A., 1966. Mise en évidence d'un contrôle hypothalamique stimulant de la prolactine hypophysaire chez le canard. C. R. Acad. Sci., Paris. 263, 162-165.

GREIBROKK T., HANSEN J., KNUDSEN R., LAM Y. F., FOLKERS K., 1975. On the isolation of a prolactin inhibiting factor (hormone). Biochem. Biophys. Res. Commun., 67, 338-344.

GROSVENOR C. E., MENA F., 1972. Effect of suckling and of exteroceptive stimulation upon prolactin release in the rat during late lactation. J. Endocrin., 52, 11-22.

GROSVENOR C. E., MENA F., 1973. Neural and hormonal control of milk secretion and milk ejection. In B. L. LARSON and V. R. SMITH, Lactation, Academic Press, New York.

GUDLEKSY G. A., SIMPKINS J., MEITES J., MOORE K. E., 1976. Effects of prolactin and haloperidol on dopamine furnover in the tuberoinfundibular and nigrostriatal pathways of the rat brain. 6th Ann. Meet. Soc. Neuroscience. Abstr. no 959. 
HERY M., LAPLANTE E., KORDON C., 1976. Participation of serotonin in the plasma release of LH. I. - Evidence from pharmacological experiments. Endocrinology, 99, 496-503.

HOKFELT T., FUXE K., 1972. Effects of prolactin and ergot alkaloids on the tuberoinfundibular dopamine neurons. Neuroendocrinology, 9, 100.

KAMBERI I. A., MICAL R. S., PORTER J. C., 1971. Effects of melatonin and serotonin on the release of FSH and prolactin. Endocrinology, 88, 1288.

KIZER J. S., ARIMURA A., SCHALLY A. V., BROWNSTEIN M. J., 1975. Absence of luteinizing hormone-releasing hormone (LH-RH) from catecholaminergic neurons. Endocrinology, 96, $523-$ 525.

KORDON C., 1973. Effect of drugs acting on brain monoamines and the control of gonadotropic secretion, P. 120. In R. O. SCOW, Endocrinology, Elzevir, N. Y.

KORDON C., BLAKE C. A., TERKEL J., SAWYER C., 1973. Participation of serotonin-containing neurons in the suckling induced rise in plasma prolactin levels in lactating rats. Neuroendocrinology, 13, 213-223.

KORDON C., GLOWINSKI J., 1972. Role of hypothalamic monoaminergic neurons in the gonadotropic release-regulating mechanisms. J. Neuropharmacol., 11, 153.

KORDON C., JAVOY F., VASSENT G., GLOWINSKI J., 1968. Blockade of superovulation in the immature rat by increased brain serotonin. Eur. J. Pharmacol., 4, 169.

KORDON C., ROTSZTEJN W. H., 1976. Subcellular distribution and neurotransmitter control of hypophysiotropic factors in the median eminence. In E. COSTA, Non-striatal dopaminergic neurons. Raven Press, New York (in press).

KRAGT C., MEITES J., 1965. Stimulation of pigeon pituitary prolactin release by pigeon hypothalamic extracts in vitro. Endocrinology, 76, 1169-1176.

LABRIE F., DE LEAN A., BARDEN N., FERLAND L., DROUIN J., BORGEAT P., BEAULIEU M., MORIN O., 1976. New aspects of the mechanism of action of hypothalamic regulatory hormones. In F. LABRIE, J. MEITES, G. PELLETIER, Hypothalamus and endocrine functions. Plenum Press, New York.

LICHTENSTEIGER W., 1969. Cyclic variations of catecholamine content in hypothalamic nerve cells during the estrous cycle of the rat with a concommittant study of the substantia nigra. J. Pharmacol. exp. Ther., 165, 204.

LU K. H., AMENOMORI Y., CHEN C. L., MEITES J., 1970. Effects of central acting drugs on serum and pituitary prolactin levels in rats. Endocrinology, 87, 667.

MC CANN S. M., KALRA P. S., DONOSO A. E., BISHOP W., SCHNEIDER H. P. G., FAWCETT C. P., KRULICH L., 1972. The role of monoamines in the control of gonadotropic and prolactin secretion, 224. In K. M. KNIGGE and W. WEINDL, Brain endocrine interactions, median eminence : structure and function, Karger, Basel.

MC LEOD R. M., LEHMEYER J. E., 1974. Studies on the mechanism of dopamine-mediated inhibition of prolactin secretion. Endocrinology, 94, 1077-1085.

MEITES J., 1970. Direct studies of the secretion of the hypothalamic hypophysiotropic hormones, 261-281. In J. MEITES, Hypophysiotropic hormones of the hypothalamus. Assay and Chemistry. William and Wilkins Baltimore.

MEITES J., NICOLL L. S., 1966. Adenohypophyseal prolactin. Ann. Rev. Physiol., 28, 57-88.

MENA F., ENJALBERT A., CARBONELL L., PRIAM M., KORDON C., 1976. Effect of suekling on plasma prolactin and hypothalamic monoamine levels in the rat. Endocrinology, 99, 445-451.

O'STEEN W. K., 1965. SUppression of ovarian activity in immature rats by serotonin. Endocrinology, $77,937$.

PASTEELS J. L., 1967. Contrôle de la sécrétion de prolactine par le système nerveux. Arch. Anot. micr. Morph. exp., 56, 530-544.

RAMIREZ V. D., GAUTRON J. P., EPELBAUM J., PATTOU E., ZAMORA A., KORDON C., 1975. Distribution of LHRH in subcellular fractions of mediobasal hypothalamus. Molec. cell, Endocr., 3, 339-350.

RICHARD P., 1970. An electrophysiological study in the ewe of the tracts which transmit impulses from the mammary glands to the pituitary stalk. J. Endocrin., 47, 37.

RICHARD P., URBAN I., DENAMUR R., 1970. The role of the dorsal tracts of the spinal cord and of the mesencephalic and thalamic lemniscal system in the milk-ejection reflex during milking in the ewe. J. Endocrin., 47, 45. 
ROTSZTEJN W. H., CHARLI J. L., PATTOU E., EPELBAUM J., KORDON C., 1976. In vitro release of luteinizing hormone releasing hormone (LH-RH) from rat medio basal hypothalamus : effects of potassium, calcium and dopamine. Endocrinology, 99, 1663-1666.

SCHALLY A. V., DUPONT A., ARIMURA A., TAKAMARA J., REDDING T. W., CLEMENS J., SHAAR C., 1976. Purification of a catecholamine-rich fraction with prolactin release inhibiting factor (PIF) activity from porcine hypothalami. Acta Endocr., 82, 1-14.

SHAAR C. J., CLEMENS J. A., 1974. The role of catecholamines in the release of anterior pituitary prolactin in vitro. Endocrinology, 95, 1202-1212.

SHIN S. M., MORRIS A., SNYDER J., HYMES W. C., MILLIGAN J. V., 1974. Subcellular localisation of LHRH in the rat hypothalamus. Neuroendocrinology, 16, 191.

SHOEMAKER W. J., 1976. Non neural cells containing catecholamines in the infundibulum. In E. COSTA, Nonstriafal dopaminergic neurons. Raven Press, New York (in press).

SMALSTIG E. B., SAWYER B. D., CLEMENS J. A., 1974. Inhibition of rat prolactin release by apomorphine in vivo and in vitro. Endocrinology, 95, 123-129.

TABER C. A., KARAVOLAS H. J., 1975. Subcellular localisation of LH releasing activity in the rat hypothalamus. Endocrinology, 96, 446-452.

TASHIIAN A. H., BAROUSKY N. J., JENSEN D. K., 1971. Thyrotropin releasing hormone : direct evidence for stimulation of prolactin production by pituitary cells in culture. Biochem. Biophys. Res. Commun., 43, 516-522.

TERKEL J., BLAKE C. A., SAWYER C. H., 1972. Serum prolactin levels in lactating rats after suckling or exposure to ether. Endocrinology, 91, 49-53.

TIXIER-VIDAL A., GOURDJI D., PRADELLES P., MORGAT J. L., FROMAGEOT P., KERDELHUÉ B., 1975. A cell-culture approach to the study of TRH receptors, 89-108. In M. MOTTA, B. J. CROSIGNANI, L. MARTINI, Hypothalamic hormone, Acad. Press, London.

UNGERSTEDT U., 1968. 6-hydroxydopamine induced degeneration of central monoamine neurons. Eur. J. Phormacol., 5, 107-110.

VOOGT J. L., CARR L. A., 1974. Plasma prolactin levels and hypothalamic calecholamine synthesis during suckling. Neuroendocrinology, 16, 108-118.

WEINER R. 1., 1975. Role of brain catecholamines in the control of $\mathrm{LH}$ and prolactin secretion. In M. MOTTA, P. G. GROSIGNANI, L. MARTINI, Hypothalamic hormones, Academic Press, London.

YOKOHAMA A., HALASZ B., SAWYER C. H., 1967. Effect of hypothalamic deafferentation on lactation in rats. Proc. Sor. exp. Biol. Med., 125, 623-626. 